\title{
Review \\ Rec8 Cohesin: A Structural Platform for Shaping the Meiotic Chromosomes
}

\author{
Takeshi Sakuno and Yasushi Hiraoka *(D)
}

check for

updates

Citation: Sakuno, T.; Hiraoka, Y. Rec8 Cohesin: A Structural Platform for Shaping the Meiotic Chromosomes. Genes 2022, 13, 200. https:/ /doi.org/ $10.3390 /$ genes 13020200

Academic Editors: Monique Zetka and Verena Jantsch

Received: 13 December 2021

Accepted: 21 January 2022

Published: 22 January 2022

Publisher's Note: MDPI stays neutral with regard to jurisdictional claims in published maps and institutional affiliations.

Copyright: (c) 2022 by the authors. Licensee MDPI, Basel, Switzerland. This article is an open access article distributed under the terms and conditions of the Creative Commons Attribution (CC BY) license (https:/ / creativecommons.org/licenses/by/ $4.0 /)$.
Graduate School of Frontier Biosciences, Osaka University, Suita 565-0871, Japan; sakuno@fbs.osaka-u.ac.jp

* Correspondence: hiraoka@fbs.osaka-u.ac.jp

\begin{abstract}
Meiosis is critically different from mitosis in that during meiosis, pairing and segregation of homologous chromosomes occur. During meiosis, the morphology of sister chromatids changes drastically, forming a prominent axial structure in the synaptonemal complex. The meiosis-specific cohesin complex plays a central role in the regulation of the processes required for recombination. In particular, the Rec8 subunit of the meiotic cohesin complex, which is conserved in a wide range of eukaryotes, has been analyzed for its function in modulating chromosomal architecture during the pairing and recombination of homologous chromosomes in meiosis. Here, we review the current understanding of Rec8 cohesin as a structural platform for meiotic chromosomes.
\end{abstract}

Keywords: meiosis; chromosome; cohesin; Rec8; Pds5; Wpl1; synaptonemal complex; axis-loop structure; homolog pairing; recombination

\section{Introduction}

Cohesin is a highly conserved protein complex that establishes cohesion between sister chromatids after DNA replication, and is essential for proper chromosome segregation during mitosis and meiosis [1,2]. Rec8, a meiosis-specific component of cohesin, plays a central role in the recombination of homologous chromosomes during meiosis $[3,4]$.

Meiosis is a unique type of eukaryotic cell division that produces gametes which are essential for sexual reproduction. In meiosis, one round of DNA replication is followed by two successive rounds of chromosome segregation, thus resulting in half the number of chromosomes in the gametes. Meiosis produces sperm and eggs in humans, and abnormalities in meiosis can cause miscarriages as well as various congenital genetic disorders, such as Down syndrome [5,6].

In the first meiotic division (meiosis I), homologous chromosomes segregate to opposite poles. This process is called reductional segregation and is essentially different from both mitosis and the second meiotic division (meiosis II), in which sister chromatids (a pair of replicated chromosomes) segregate to opposite poles (Figure 1) [3]. To correctly accomplish reductional segregation in meiosis I, homologous chromosomes need to be physically linked to each other via the chiasmata, a product of crossing over (the exchange of DNA sequences between homologous chromosomes) during the meiotic prophase. In almost all eukaryotes, homologous chromosomes are spatially separated in the nucleus during mitosis, but they become paired during the meiotic prophase, by first identifying the correct partner and then moving into physical proximity (pairing). Pairing is stabilized by the synaptonemal complex (SC), which holds homologous axes together along its entire length (synapsis) (Figure 2). The SC is composed of two lateral elements, each of which is derived from an axial element formed along a pair of sister chromatids, and the central region, which is composed of transverse filaments (i.e., Zip1 in budding yeast or SYCP1 in mice) which connect the lateral elements of each homologous chromosome (Figure 2) [7,8]. However, homologous chromosomes can pair without SCs, even in SC-forming organisms [9-11]. Moreover, homologous pairing also occurs in asynaptic organisms, such as the fission yeast Schizosaccharomyces pombe, which does not form a typical SC [12-14]. 


\section{mitosis}

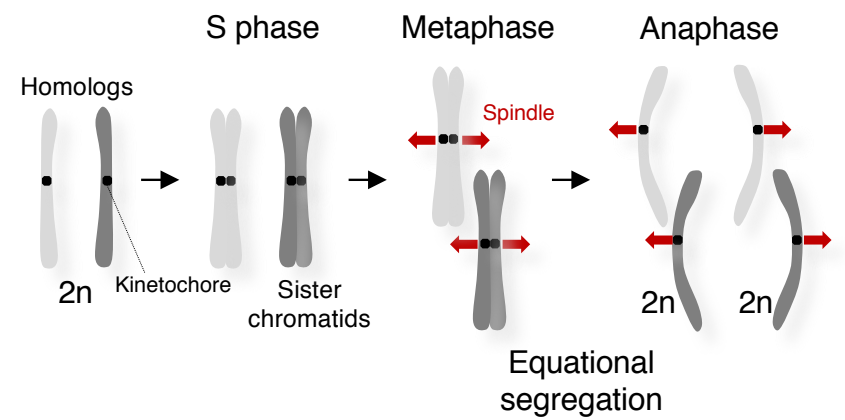

\section{meiosis}

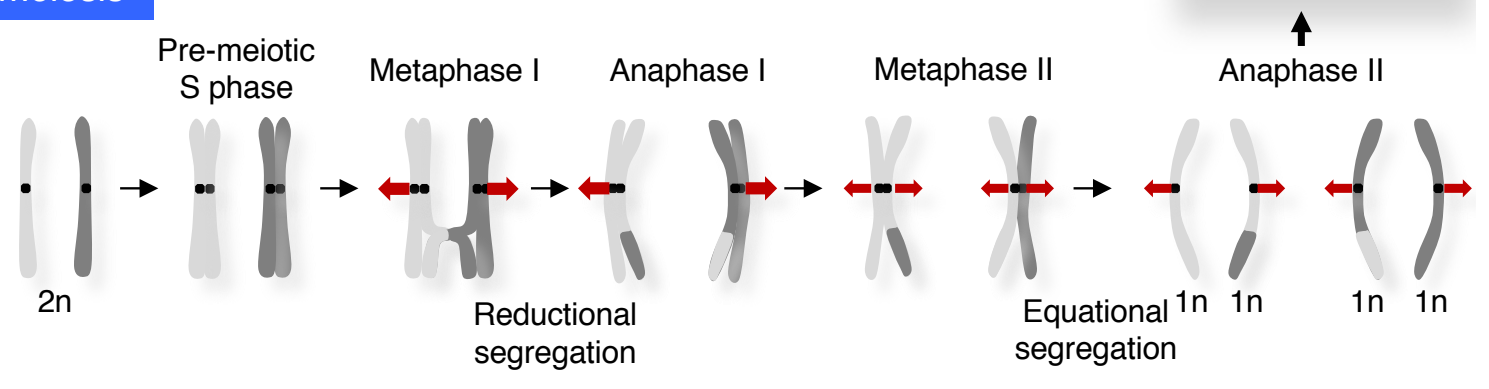

Figure 1. Chromosome segregation during mitosis and meiosis. Schematic diagram of chromosome segregation patterns during mitosis and meiosis. The picture shows spores of Schizosaccharomyces pombe produced after meiosis.

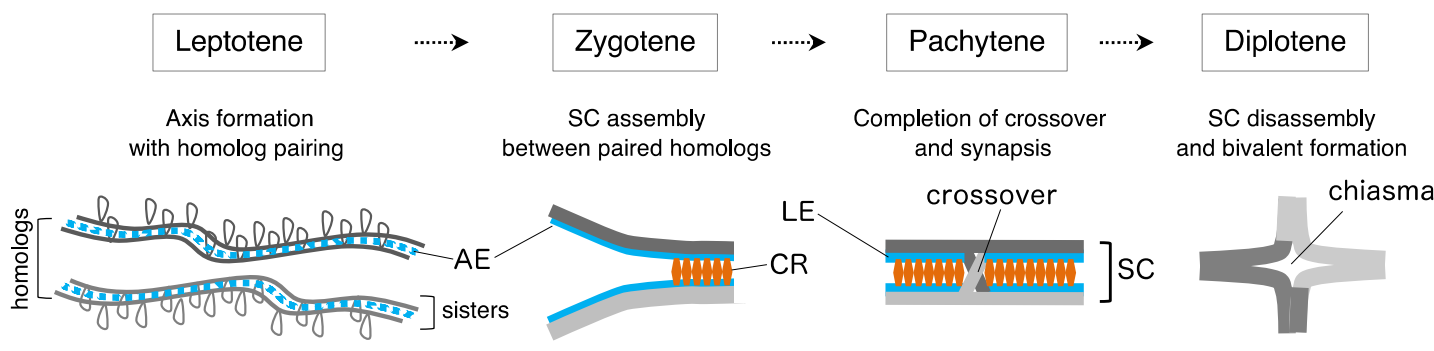
AE: Axial Element
LE: Lateral Element
CR: Central Region
SC: Synaptonemal complex

Figure 2. Chromosome organization during meiotic prophase. Schematic representation of chromosome organization during meiotic prophase in synaptonemal complex (SC)-forming organisms. Meiotic prophase is divided into four distinct stages: leptotene, zygotene, pachytene, and diplotene. The axial element (AE) is the precursor of the lateral element (LE) of the SC.

The Rec8-containing cohesin complex (Rec8 cohesin) is essential for the assembly of lateral elements, which are required for SC formation and homologous recombination in a wide range of eukaryotes [15-25]. Even in asynaptic organisms, Rec8 cohesin forms an axial structure resembling the lateral element, which is essential for homologous recombination during meiosis [26-32]. In addition to these canonical roles of Rec8 cohesin in recombination, recent developments in technologies, such as genome-wide chromosome conformation capture, have revealed roles for Rec8 cohesin in meiotic chromosome architecture [33-36]. This review highlights the role of Rec8 cohesin in meiosis, which is common in both SC-forming and asynaptic organisms.

\section{Components of Cohesin Complexes}

The mitotic cohesin complex consists of four core subunits, two structural maintenance of chromosome (SMC) family proteins, Smc1 and Smc3, and two non-SMC kleisin subunits, 
Scc1 and Scc3 (Scc1 is also called Mcd1 in the budding yeast Saccharomyces cerevisiae, and Rad21 in several other organisms; Scc3 is also called SA1/2 in metazoans, and Psc3 in S. pombe) (Figure 3A,B) [37]. It has been proposed that the cohesin complex forms a ring structure that topologically entraps two sister chromatids together; alternatively, two cohesin rings, each entrapping one sister chromatid, are held together [38,39].

A

S. pombe mitotic cohesin complex

S. pombe meiotic cohesin complex
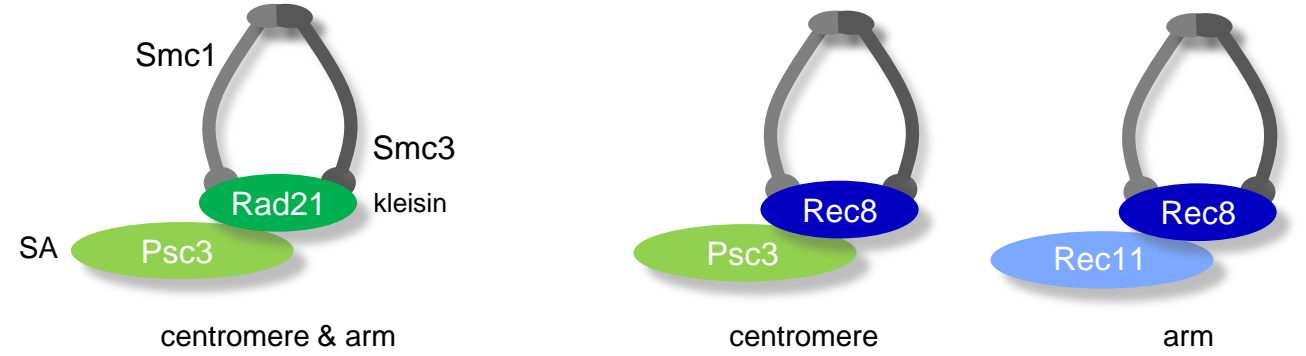

B

\begin{tabular}{|c|c|c|c|c|c|c|c|c|c|c|}
\hline & \multicolumn{2}{|c|}{ S. pombe } & \multicolumn{2}{|c|}{ S. cerevisiae } & \multicolumn{2}{|c|}{ C. elegans } & \multicolumn{2}{|c|}{ D. melanogaster } & \multicolumn{2}{|c|}{$\begin{array}{l}\text { H. sapiens } \\
\text { M. musculus }\end{array}$} \\
\hline & Constitutive & $\begin{array}{l}\text { Meiosis } \\
\text { specific }\end{array}$ & Constitutive & $\begin{array}{l}\text { Meiosis } \\
\text { specific }\end{array}$ & Constitutive & $\begin{array}{l}\text { Meiosis } \\
\text { specific }\end{array}$ & Constitutive & $\begin{array}{l}\text { Meiosis } \\
\text { specific }\end{array}$ & Constitutive & $\begin{array}{l}\text { Meiosis } \\
\text { specific }\end{array}$ \\
\hline \multirow{2}{*}{ SMC } & Psm1 & & Smc1 & & SMC-1 & & Smc1 & & SMC1a & SMC1 $1 \beta$ \\
\hline & Psm3 & & Smc3 & & SMC-3 & & Smc3 & & SMC3 & \\
\hline kleisin & Rad21 & Rec8 & Scc1 & Rec8 & SCC-1 & $\begin{array}{c}\text { REC-8 } \\
\mathrm{COH}-3 / 4\end{array}$ & Rad21 & $c(2) M$ & $\begin{array}{l}\text { RAD21/ } \\
\text { SCC1 }\end{array}$ & $\begin{array}{c}\text { REC8 } \\
\text { RAD21L }\end{array}$ \\
\hline SA & Psc3 & Rec11 & Scc3 & & SCC-3 & & SA & & $\begin{array}{c}\text { STAG } 1 / 2 \\
\text { (SA1/2) }\end{array}$ & $\begin{array}{c}\text { STAG3 } \\
\text { (SA3) }\end{array}$ \\
\hline
\end{tabular}

Figure 3. Cohesin complex in mitosis and meiosis. (A). A schematic diagram of cohesin complexes in Schizosaccharomyces pombe. During mitosis in S. pombe, the Rad21-Psc3 cohesin complex is distributed at the centromere and along the chromosome arm. During meiosis, the Rec8-Psc3 cohesin complex is localized only at the centromere, whereas the Rec8-Rec11 cohesin complex is distributed along the chromosome arms. (B). Nomenclature for the subunits of the cohesin complex in representative eukaryotic model organisms. The constitutively expressed subunits and the meiosis-specific subunits are shown.

The meiotic cohesin complex uses subunits that differ from those involved in mitosis. In most species, the vast majority of $\operatorname{Rad} 21$ and SA1/2 subunits are replaced by meiosis-specific subunits, namely Rec8 and SA3, respectively (Figure 3B). In vertebrates, Smc1 $\beta$ is expressed in addition to Smc1, and a meiosis-specific kleisin, Rad21L, is also expressed [40-42]. In many species, these meiosis-specific subunits are required not only for sister chromatid cohesion, but also for the formation of the axial element, which serves as a scaffold for recombination reactions within the SC [8].

\section{Roles of Meiotic Cohesin in Chromosomal Events}

Homologous chromosomes must be paired and recombined during meiosis to ensure proper segregation of homologous chromosomes. Meiosis-specific subunits of cohesin play an essential role in these meiotic chromosomal events.

\subsection{Pairing of Homologous Chromosomes}

A striking example of asynaptic pairing of homologous chromosomes can be observed in S. pombe. In S. pombe, pairing of homologous chromosomes depends highly on the oscillatory movement of the nucleus (so-called "horsetail" movement) with the telomeres bundled 
at the spindle pole body (SPB) generating a bouquet orientation of chromosomes [26,43-47]. In $S$. pombe, the pairing of homologous chromosomes is achieved during horsetail nuclear movement in the absence of DNA double-strand breaks (DSBs) introduced by Rec12 (Spo11 in S. cerevisiae). Nevertheless, pairing of homologous chromosomes requires Rec8 cohesin, indicating that meiotic cohesin plays a role in homolog pairing independent of Rec12mediated DSB or SC formation. Torsional turning of chromosomes, which occurs when the SPB changes the direction of nuclear movement, is thought to promote the alignment of homologous chromosomes (Figure 4A) [48]. Such chromosome movements promote homologous pairing and at the same time, eliminate non-homologous interaction [48,49]. Meiosis-specific chromosome movements caused by the attachment of telomeres to the nuclear membrane also contribute to the initiation of pairing in other organisms $[50,51]$.

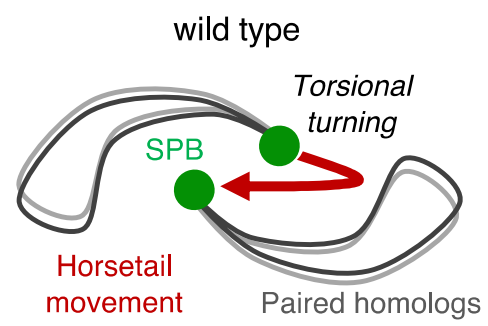

B

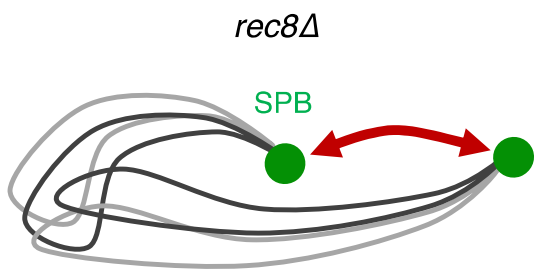

Figure 4. Horsetail nuclear movement in meiosis. Schematic diagrams of chromosome movement in wild-type (A) and $\operatorname{rec} 8 \Delta$ (B) cells.

Additionally, it has been shown that in S. pombe, noncoding RNAs and their associated factors, called sme2 RNA-associated proteins (Smp), contribute to the DSB-independent pairing of homologous chromosomes $[43,45,52]$. It should be noted that non-coding RNAmediated pairing of homologous chromosomes in $S$. pombe requires Rec8 [45,53-55]. In rec $8 \Delta$ meiotic cells of $S$. pombe, the oscillatory movement of SPB and bouquet orientation appear to be normal $[32,54,55]$. However, the bulk of the chromosomes are stuck, protruding from the leading edge of the nucleus during horsetail movement, resulting in defective pairing in rec $8 \Delta$ cells (Figure 4B) [54,55]. Therefore, during horsetail nuclear movement, compromised chromosome motion in rec $8 \Delta$ cells without torsional turning of chromosomes could lead to pairing defects. This abnormal chromosomal behavior in rec $8 \Delta$ cells might occur because the traction force that drives whole chromosomes is not well transmitted to the entire chromosome, owing to a loss of chromosome structure in the absence of Rec8 cohesin.

\subsection{Regulation of Recombination Bias between Homologous Chromosomes and Sister Chromatids}

During the repair of DSBs, which occurs spontaneously during mitosis, Scc1/Rad21 mitotic cohesin promotes damage-induced homologous recombination between sister chromatids, suppressing recombination between homologous chromosomes [56]. This is called sister bias, and is presumably caused by the spatial proximity of sister chromatids due to cohesin-dependent sister chromatid cohesion. In contrast, during meiotic prophase, DSBs introduced by Spo11 are repaired by homologous recombination, which preferentially uses homologous chromosomes and not sister chromatids as templates, a mechanism called homolog bias [57,58]. The physical proximity of homologous chromosomes via pairing or SC formation is an essential prerequisite for establishing homolog bias. In addition, studies in S. cerevisiae have suggested that this bias is facilitated by the cooperative function of Rec 8 cohesin with components of axial elements, such as Red1, Hop1, and Mek1 [59,60]. Interestingly, in the absence of these axial components, sister bias was induced in a Rec8 cohesin-dependent manner, suggesting that Rec8 cohesin which is responsible for sister chromatid cohesion during meiosis also potentially plays a role in sister bias in Spo11-induced meiotic recombination as well as Scc1/Rad21 cohesin during mitosis [59]. However, the functions of Rec 8 cohesin can be modified and regulated to promote homolog 
bias by several factors, including components of the axial element. The conservation of this homolog bias across eukaryotes is not apparent, but it seems to be absent in fission yeast [61].

\subsection{Segregation of Homologous Chromosomes and Sister Chromatids}

After physical links are established between homologous chromosomes via the chiasmata as a result of crossing over, homologous chromosomes segregate to opposite poles (reductional segregation) during meiosis I. In metaphase I, sister kinetochores behave as a single unit and establish mono-polar attachment; specifically, sister kinetochores are captured by spindle microtubules emanating from one pole (Figure 5). Because of the cooperative action of this mono-polar attachment and the chiasmata, tension is generated between homologous chromosomes; thus, spindles successfully pull homologous chromosomes toward both poles $[3,15,62-69]$. In $S$. pombe, it has been shown that in meiosis I, sister kinetochores are connected by the Rec8 cohesin-mediated cohesion around the centromeric region [70]. More recently, this type of Rec8 cohesin-dependent cohesion at the centromere was shown to be necessary for mono-polar meiosis I attachment in female mice [71]. The establishment of Rec8 cohesin-dependent centromeric cohesion is regulated by meiosis-specific kinetochore factors called Meikin family proteins, Moa1 in S. pombe, Spo13 in S. cerevisiae, and Meikin in mice [72-77]. The precise functions of Meikin family proteins are still unknown, but it has been reported that Meikin recruits polo-like kinases to the kinetochore, and this kinase has essential functions in establishing mono-polar attachment [72-74]. In S. cerevisiae, in addition to regulation by Spo13, mono-polar attachment is also regulated by a different set of meiosis-specific kinetochore protein complexes called monopolins, including Mam1, Csm1, Lrs4, and Hrr25 [68,69,78].

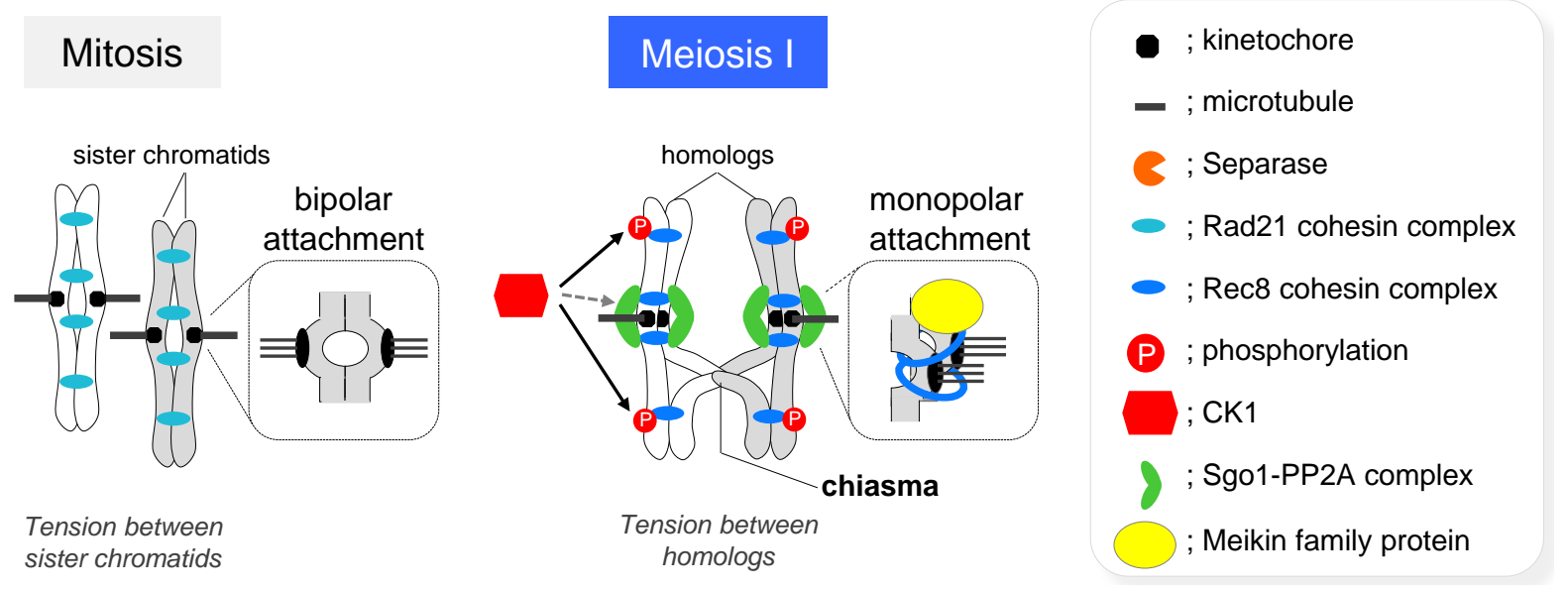

Figure 5. Molecular details of the regulation of chromosome segregation in meiosis I. A schematic diagram of the state of chromosomes immediately before segregation in mitosis (left) and meiosis I (right).

Rec8 cohesin holds homologous chromosomes together via sister chromatid cohesion, and this state is maintained in the vicinity of the crossing over site until anaphase I, resulting in retention of physical interaction of homologous chromosomes via the chiasma [3,79]. Subsequently, at the onset of anaphase I, cohesin complexes are dissociated from chromosomes by separase, a cysteine endoprotease which cleaves the kleisin subunit of cohesin, thus allowing the separation of homologous chromosomes. Importantly, although cohesin at the chromosome arms is degraded by separase in anaphase I, cohesin at the centromere is protected from degradation $[15,80]$. As a result, sister chromatids remain associated at the centromere through cohesion via Rec8 cohesin. Subsequently, in meiosis II, sister chromatids are evenly segregated, similar to somatic cell division, by releasing the remaining cohesion at the centromeres (Figure 5). It has been reported that the frequency of crossing 
over at centromeres is approximately 5-100 times lower than that at similar distances in chromosome arms in several organisms [81-83]. Frequent crossing over at the centromere causes loss of centromeric cohesion leading to meiosis II failure and aneuploid gametogenesis $[84,85]$. Therefore, suppression of crossing over at centromeric regions is essential for proper chromosome segregation during meiosis II. In addition, studies in S. pombe have identified that Sgo1 protects Rec8 from cleavage by separase around the centromere during anaphase I [86-88]. Sgo1 is specifically expressed during meiosis and localizes to the centromeric region. Rec8 is phosphorylated by type I casein kinase $\delta / \varepsilon(C K 1)$, which makes it susceptible to degradation by separase. In contrast, PP2A phosphatase, which interacts with Sgo1, localizes to the centromere. Therefore, at the centromere, phosphorylation of Rec 8 by CK1 was reversed by PP $2 \mathrm{~A}$. Consequently, Rec 8 at the centromere is protected from degradation by separase [89-91]. Furthermore, when the expression of mouse shugoshin is suppressed in oocytes, $\operatorname{Rec} 8$ at the centromere is degraded prematurely in anaphase I, consistent with findings in sgo1 $\Delta$ mutants of $S$. pombe [92,93]. Thus, meiotic cohesin protection mechanism of Sgo1 is evolutionarily conserved. Therefore, many crucial processes are regulated by Rec 8 cohesin during meiosis, which is an essential event for sexual reproduction in eukaryotes.

\section{Roles of Meiotic Cohesin in Chromosome Architecture}

Forced expression of Rad21 during meiosis in the absence of Rec8 partially recovers sister chromatid cohesion, but does not compensate for defects in meiosis-specific chromosome events, including reductional segregation [65,69]. Moreover, formation of SCs in S. cerevisiae and the axial structure of chromosomes in $S$. pombe during meiosis are defective in $r e c 8 \Delta$ mutants, even with the ectopic expression of Scc1/Rad21 [35,69]. Therefore, $\operatorname{Rec} 8$ cohesin may play additional roles other than cohesion in regulating meiotic chromosome behavior, such as SC formation, associated with axial structure.

\subsection{Formation of Axial Elements}

The axial element is a precursor of the lateral element of the SC, and corresponds to the LinE in in asynaptic organisms such as S. pombe. In the SC-forming organism $S$. cerevisiae, the formation of the axial element during the meiotic prophase is defective in rec8 mutants, specifically affecting Hop1 and Red1, which are both structural components of the axial element and do not form linear structures in rec 8 mutants, as observed by electron microscopy of the meiotic prophase nuclei [15]. Rec8 interacts with Red1 (Rec10 in S. pombe and SYCP2 in mice) and Hop1 [94]. Because Rec8 is required for correct localization of Red1 and Hop1 to the chromosomal axis sites [94,95], Rec8 is essential for recruiting Red1 and Hop1 to a subset of meiotic chromosomal positions, at least in S. cerevisiae [94].

In $S$. pombe, Rec8 cohesin contains a meiosis-specific SA3 subunit called Rec11. No obvious homolog of SA3 has been found in S. cerevisiae. Importantly, it has been shown that the N-terminal region of Rec11 is phosphorylated by CK1 during meiosis [96,97]. This phosphorylation induces an interaction between Rec11 and Rec10 (a homolog of S. cerevisiae Red1, which is a structural component of LinE in S. pombe). This interaction further results in the recruitment of Rec10 and other LinE components, such as Hop1, Rec25, and Rec27, onto chromatin, and induce LinE assembly along sister chromatids [96]. As implied by its gene name, Rec8, Rec10, and Rec11 in S. pombe were originally isolated as mutants deficient in meiotic recombination [98]. LinE is necessary for the recruitment of recombination apparatus, such as Rec12 (Spo11 homolog in S. pombe), along the chromatin [99]. Therefore, the mechanism by which cohesin and LinE cooperate to regulate recombination in $S$. pombe may explain the recombination-defective phenotype in these mutants.

In mice, in addition to Rec8, the meiosis-specific subunits SA3 (Rec11 homolog), kleisin subunit Rad21L, and Smc1 $\beta$ are required for the assembly of axial elements during the meiotic prophase [20-25,100,101]. Moreover, chromatin-bound cohesins, including SA3, are highly phosphorylated during the meiotic prophase in mouse spermatocytes [102]. Therefore, it is possible that phosphorylation of the cohesin complex contributes to the 
meiotic chromosome axis assembly in mammalian meiosis, similar to $S$. pombe. Rec8 cohesin is also required for the assembly of axial elements in Arabidopsis thaliana and Caenorhabditis elegans [16-18,103]. Therefore, the meiosis-specific cohesin complex has conserved functions in a wide range of organisms and regulates meiotic recombination by assembling axis structures along sister chromatids by recruiting structural components of the axial element.

\subsection{Formation of the Axis-Loop Chromatin Structure}

Importantly, studies using mouse spermatocytes have demonstrated that the loss of SYCP2 or SYCP3, structural components of the axial element, disrupts the formation of axial elements, but generally results in retention of the cohesin axis, which is visualized by immunostaining of cohesin subunits in meiotic prophase cells [25,104,105]. Similarly, in S. pombe, LinE formation-defective mutants, but not rec8 mutants, maintain structural properties of chromatin to withstand oscillatory nuclear movement during meiotic prophase $[54,96]$. These results strongly suggest that Rec8 cohesin-induced chromosome structure is independent of the axial elements (or LinEs in S. pombe). In addition, previous electron microscopy observations have detected axial structures with chromatin loops (axis-loop chromatin structure), such as those now thought to be mediated by Rec8 cohesin $[33-35,106]$. Furthermore, recent studies in several organisms using high-throughput chromosome conformation capture (Hi-C) have depicted the configuration of meiotic chromosomal structures [33,107-115]. Importantly, it has been reported that Rec8 localization correlates with regions of contacts detected by Hi-C, which represent the bases of chromatin loops in S. cerevisiae $[33,34,116]$. Moreover, these loops are lost in the absence of Rec8 cohesins [33]. Therefore, it is now clear that the axis structure with chromatin loops is mediated by Rec8 cohesin during meiosis.

In contrast, chromatin loops are undetectable via Hi-C in mammalian meiosis [107,109,110], despite clear observation of chromatin loop structures in mouse meiotic chromosomes by electron microscopy $[117,118]$. It has been argued that the chromosomal position of Rec8 or the loop location varies from cell to cell in mammals [107]. In somatic cells of several organisms, Rad21/Scc1 cohesins have the ability to form higher-order structures called topologically associated domains (TADs) by pulling together distant regions of chromosomes, which can at times be up to several Mbp [119-123]. In mammalian meiosis, TAD signals observed in mitotic interphase cells mostly disappear $[107,109,110]$. This suggests that switching of protein subunits is essential to construct chromosomes that are ready for subsequent meiotic recombination, probably by exchanging cohesins from mitotic RAD21 to its meiotic counterparts along the chromosomes.

Recently, Hi-C analysis in S. pombe has revealed the appearance of chromatin loops between known Rec8-binding sites upon entry into meiosis [35]. These loop structures are completely lost in rec8 $\Delta$ cells. However, in rec12 $\Delta$ (Spo11 homolog of S. pombe) mutants, in which recombination never occurs, these loop structures are normally maintained. Moreover, the normal formation of loop structures is also observed in rec10 $\Delta$ cells, in which LinE is not assembled. In addition, similar to those in mammalian spermatocytes, with the emergence of Rec8-dependent loop structures, TAD-like signals observed in mitotic interphase cells mostly disappear during the meiotic prophase [35]. This could be mainly due to the switching of kleisin subunits from Rad21 to Rec8, which occurs upon commitment to meiosis. Although Rec8-cohesin-dependent loop structures have been detected in S. pombe and S. cerevisiae [33-35], the mechanism through which loop formation and sister chromatid cohesion are coordinately regulated as well as the contribution of $\operatorname{Rad} 21 /$ Scc1 cohesin remains unclear. It has been proposed that two separate populations of Rec8 cohesin act on loop formation and cohesion [34]. In mouse oocyte meiosis, it has been suggested that RAD21/SCC1 and REC8 cohesins have distinct functions in chromatin loop formation and cohesion, respectively [36,108]. Functions of the kleisin subunits in meiotic chromatin structure may differ among species. 
Considering the cohesin-mediated axial loop structure of chromosomes during meiosis, it is necessary to consider the cohesin regulators Pds5 and Wpl1/WAPL. Pds5 is a cohesin-associated factor thought to maintain cohesion during mitosis [124-127]. However, it has been shown that WAPL interaction with PDS5 promotes the release of mitotic cohesin from the chromosome arms prior to anaphase onset independently of separase in mammals (Figure 6) [128-130]. Additionally, in S. cerevisiae, Wpl1 releases Rec8 cohesin from chromosomes during the meiotic prophase [131,132]. Interestingly, consistent with findings in WAPL-depleted mammalian somatic cells [108,131,133-136], shortening of the chromatin axis was also commonly observed in Pds5 and Wpl1/WAPL-depleted meiotic cells in S. pombe, S. cerevisiae, C. elegans, and mice [35,54,131,132,136-138]. Concomitant with shortening of the axial structure, lengthening of the chromatin loop has also been observed $[35,133,139]$. Taken together, this suggests that Pds5 and Wp11/WAPL have a conserved function that maintains the full axis length of meiotic chromosomes (Figures 6 and 7). Intriguingly, in S. cerevisiae and S. pombe meiotic cells, the loss of Pds5 results in a pairing defect similar to that observed in rec8 $\Delta$ meiotic cells [55,137]. Moreover, S. pombe meiotic wpl1 $\Delta$ cells are defective in homologous pairing [35]. These results suggest that Pds5 and Wpl1/WAPL modulate Rec 8 cohesin axis-loop structures, acting as a structural platform that facilitates pairing and subsequent recombination during meiosis.

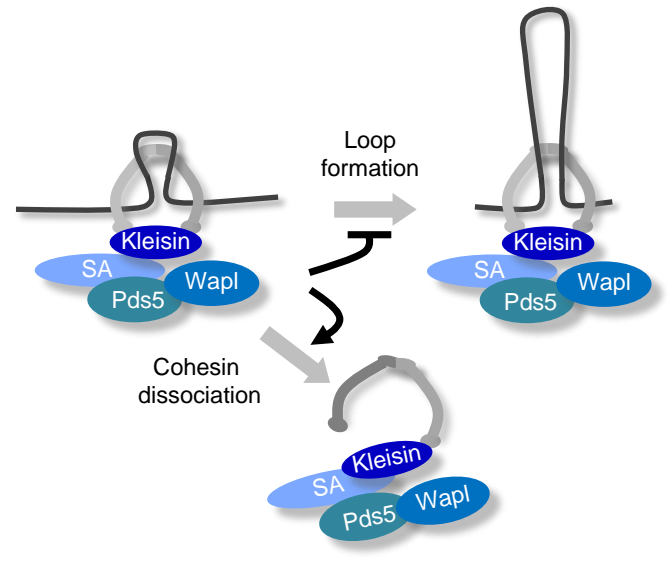

Figure 6. Proposed functions of Pds5/Wapl in the regulation of cohesin. PDS5/WAPL inhibits loop formation and promotes cohesin dissociation from chromatin. Conformational changes or unknown regulatory factors may be involved at each step to modulate the functions of Pds5 and Wapl.
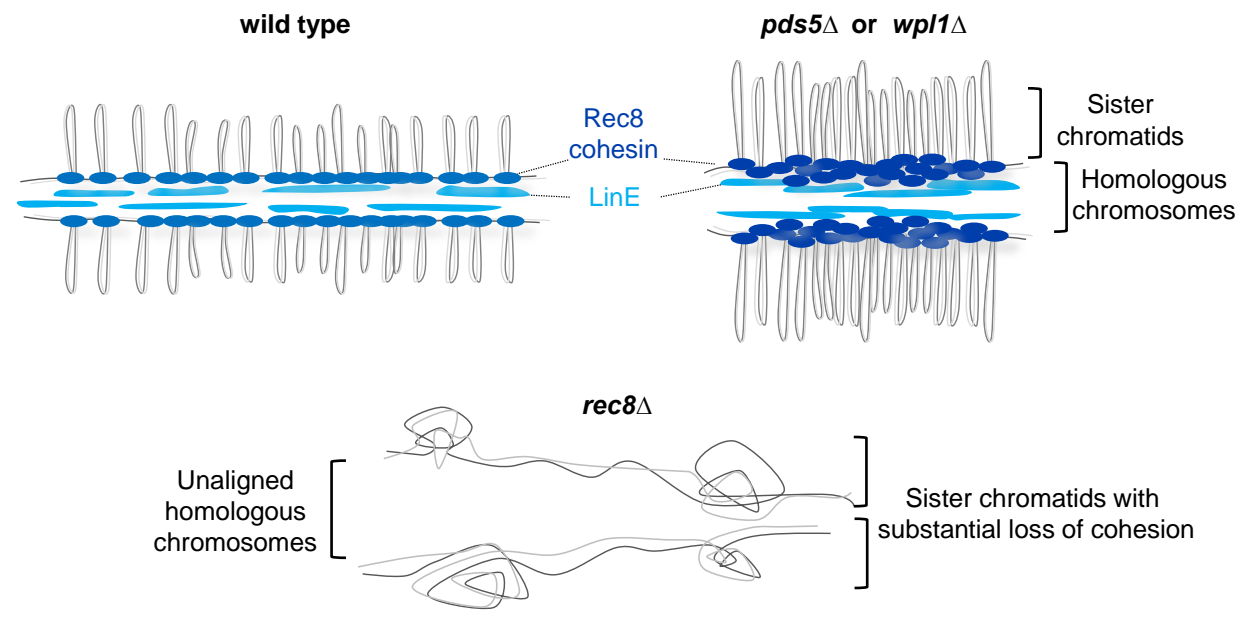

Figure 7. Chromosome architectures regulated by Pds5, Wpl1 and Rec8 in S. pombe. The Rec8dependent loop-axis structure and linear element (LinE) are shown. It is unclear whether the same Rec8 cohesin complex is responsible for both cohesion and loop formation or whether different subsets of $\operatorname{Rec} 8$ cohesin are used at each step separately. 


\section{Perspective}

In this review, we highlighted Rec 8 cohesin-dependent formation of the axis-loop structure of chromatin and its role in pairing and recombination during the meiotic prophase. In mammalian somatic cells, cis-looping of the distal chromatin or TAD formation occurs via the SCC1/RAD21 cohesin during interphase. Interestingly, the SCC1/RAD21 cohesin forms an axial structure in WAPL-depleted mammalian somatic cells. Thus, Rad21 cohesin also seems to have the potential to regulate the formation of axial structures, albeit in a mechanism different from Rec8. In mammalian somatic cells, RAD21 cohesin complexes are anchored to chromatin via the CCCTC-binding factor (CTCF) [139-142], leading to the creation of TADs. To date, it is unknown whether CTCF functions in establishing meiotic chromosomes with an axis and looping. Recently, a loop extrusion model has been proposed to create a chromatin loop via SMC protein complexes, including cohesin. In this proposed model, the SMC protein complex interacts with DNA, which reels and extrudes it through its ring structure to form a DNA loop [143-147]. The human RAD21/SCC1 cohesin can extrude DNA with the cohesin loading factors NIPBL and MAU2 in vitro [143], although it is unknown whether the loop extrusion model is applicable in vivo, whereas CTCF is a conserved factor only in vertebrates [148], NIPBL/Scc2 and MAU2/Scc4 are conserved in a wide range of eukaryotes from yeasts to humans. Therefore, it is possible to consider a scenario in which Rec8 cohesin might function with a cohesin loader for axes and loops along the meiotic chromosomes.

Loss-of-function mutations of cohesin-related factors are known to be responsible for human diseases called "cohesinopathies", such as Cornelia de Lange Syndrome which is characterized by mental retardation, facial dysmorphism, upper limb abnormalities, and growth delay $[149,150]$. In addition, defects in the regulation of meiotic recombination by meiotic cohesins are closely associated with miscarriages and congenital abnormalities in humans $[5,6]$. Therefore, it is important to elucidate the contribution of cohesin-induced axes and loop structure formation to the etiology of these human diseases.

Author Contributions: Conceptualization, T.S. and Y.H.; writing-original draft preparation, T.S. and Y.H.; writing-review and editing, T.S. and Y.H. All authors have read and agreed to the published version of the manuscript.

Funding: This research was funded by KAKENHI grants: JP18H05533 and JP20H00454 to Y.H.

Acknowledgments: We would acknowledge Tokuko Haraguchi for her continuous, encouraging, and insightful discussion.

Conflicts of Interest: The authors declare no conflict of interest. The funders had no role in the design of the study; in the collection, analyses, or interpretation of data; in the writing of the manuscript; or in the decision to publish the results.

\section{References}

1. Nasmyth, K. Segregating sister genomes: The molecular biology of chromosome separation. Science 2002, 297, 559-565. [CrossRef] [PubMed]

2. Uhlmann, F. Chromosome cohesion and segregation in mitosis and meiosis. Curr. Opin. Cell Biol. 2001, 13, 754-761. [CrossRef]

3. Petronczki, M.; Siomos, M.F.; Nasmyth, K. Un menage a quatre: The molecular biology of chromosome segregation in meiosis. Cell 2003, 112, 423-440. [CrossRef]

4. Lee, J.Y.; Orr-Weaver, T.L. The molecular basis of sister-chromatid cohesion. Annu. Rev. Cell Dev. Biol. 2001, 17, 753-777. [CrossRef] [PubMed]

5. Nagaoka, S.I.; Hassold, T.J.; Hunt, P.A. Human aneuploidy: Mechanisms and new insights into an age-old problem. Nat. Rev. Genet. 2012, 13, 493-504. [CrossRef] [PubMed]

6. Webster, A.; Schuh, M. Mechanisms of Aneuploidy in Human Eggs. Trends Cell Biol. 2017, 27, 55-68. [CrossRef] [PubMed]

7. Kleckner, N. Chiasma formation: Chromatin/axis interplay and the role(s) of the synaptonemal complex. Chromosoma 2006, 115, 175-194. [CrossRef]

8. Grey, C.; de Massy, B. Chromosome Organization in Early Meiotic Prophase. Front. Cell Dev. Biol. 2021, 9, 688878. [CrossRef] [PubMed]

9. Gerton, J.L.; Hawley, R.S. Homologous chromosome interactions in meiosis: Diversity amidst conservation. Nat. Rev. Genet. 2005, 6, 477-487. [CrossRef] 
10. Barzel, A.; Kupiec, M. Finding a match: How do homologous sequences get together for recombination? Nat. Rev. Genet. 2008, 9, 27-37. [CrossRef]

11. Zickler, D.; Kleckner, N. Recombination, Pairing, and Synapsis of Homologs during Meiosis. Cold Spring Harb. Perspect. Biol. 2015, 7, a016626. [CrossRef]

12. Niwa, O.; Shimanuki, M.; Miki, F. Telomere-led bouquet formation facilitates homologous chromosome pairing and restricts ectopic interaction in fission yeast meiosis. EMBO J. 2000, 19, 3831-3840. [CrossRef] [PubMed]

13. Scherthan, H.; Bähler, J.; Kohli, J. Dynamics of chromosome organization and pairing during meiotic prophase in fission yeast. J. Cell Biol. 1994, 127, 273-285. [CrossRef]

14. Yamamoto, A.; West, R.R.; McIntosh, J.R.; Hiraoka, Y. A cytoplasmic dynein heavy chain is required for oscillatory nuclear movement of meiotic prophase and efficient meiotic recombination in fission yeast. J. Cell Biol. 1999, 145, 1233-1249. [CrossRef] [PubMed]

15. Klein, F.; Mahr, P.; Galova, M.; Buonomo, S.B.C.; Michaelis, C.; Nairz, K.; Nasmyth, K. A central role for cohesins in sister chromatid cohesion, formation of axial elements, and recombination during yeast meiosis. Cell 1999, 98, 91-103. [CrossRef]

16. Pasierbek, P.; Jantsch, M.; Melcher, M.; Schleiffer, A.; Schweizer, D.; Loidl, J. A Caenorhabditis elegans cohesion protein with functions in meiotic chromosome pairing and disjunction. Genes Dev. 2001, 15, 1349-1360. [CrossRef]

17. Cai, X.; Dong, F.; Edelmann, R.E.; Makaroff, C.A. The Arabidopsis SYN1 cohesin protein is required for sister chromatid arm cohesion and homologous chromosome pairing. J. Cell Sci. 2003, 116, 2999-3007. [CrossRef]

18. Golubovskaya, I.N.; Hamant, O.; Timofejeva, L.; Wang, C.J.; Braun, D.; Meeley, R.; Cande, W.Z. Alleles of afd1 dissect REC8 functions during meiotic prophase I. J. Cell Sci. 2006, 119, 3306-3315. [CrossRef]

19. Xu, H.; Beasley, M.D.; Warren, W.D.; van der Horst, G.T.; McKay, M.J. Absence of mouse REC8 cohesin promotes synapsis of sister chromatids in meiosis. Dev. Cell 2005, 8, 949-961. [CrossRef]

20. Ishiguro, K.; Kim, J.; Shibuya, H.; Hernandez-Hernandez, A.; Suzuki, A.; Fukagawa, T.; Shioi, G.; Kiyonari, H.; Li, X.C.; Schimenti, J.; et al. Meiosis-specific cohesin mediates homolog recognition in mouse spermatocytes. Genes Dev. 2014, 28, 594-607. [CrossRef]

21. Fukuda, T.; Fukuda, N.; Agostinho, A.; Hernandez-Hernandez, A.; Kouznetsova, A.; Hoog, C. STAG3-mediated stabilization of REC8 cohesin complexes promotes chromosome synapsis during meiosis. EMBO J. 2014, 33, 1243-1255. [CrossRef] [PubMed]

22. Hopkins, J.; Hwang, G.; Jacob, J.; Sapp, N.; Bedigian, R.; Oka, K.; Overbeek, P.; Murray, S.; Jordan, P.W. Meiosis-specific cohesin component, Stag3 is essential for maintaining centromere chromatid cohesion, and required for DNA repair and synapsis between homologous chromosomes. PLoS Genet. 2014, 10, e1004413. [CrossRef] [PubMed]

23. Llano, E.; Gomez, H.L.; Garcia-Tunon, I.; Sanchez-Martin, M.; Caburet, S.; Barbero, J.L.; Schimenti, J.C.; Veitia, R.A.; Pendas, A.M. STAG3 is a strong candidate gene for male infertility. Hum. Mol. Genet. 2014, 23, 3421-3431. [CrossRef] [PubMed]

24. Winters, T.; McNicoll, F.; Jessberger, R. Meiotic cohesin STAG3 is required for chromosome axis formation and sister chromatid cohesion. EMBO J. 2014, 33, 1256-1270. [CrossRef]

25. Fujiwara, Y.; Horisawa-Takada, Y.; Inoue, E.; Tani, N.; Shibuya, H.; Fujimura, S.; Kariyazono, R.; Sakata, T.; Ohta, K.; Araki, K.; et al. Meiotic cohesins mediate initial loading of HORMAD1 to the chromosomes and coordinate SC formation during meiotic prophase. PLoS Genet. 2020, 16, e1009048. [CrossRef]

26. Loidl, J.S. pombe linear elements: The modest cousins of synaptonemal complexes. Chromosoma 2006, 115, 260-271. [CrossRef]

27. Bähler, J.; Wyler, T.; Loidl, J.; Kohli, J. Unusual nuclear structures in meiosis prophase of fission yeast: A cytological analysis. J. Cell Biol. 1993, 121, 241-256. [CrossRef]

28. Davis, L.; Rozalen, A.E.; Moreno, S.; Smith, G.R.; Martin-Castellanos, C. Rec25 and Rec27, novel linear-element components, link cohesin to meiotic DNA breakage and recombination. Curr. Biol. 2008, 18, 849-854. [CrossRef]

29. Estreicher, A.; Lorenz, A.; Loidl, J. Mug20, a novel protein associated with linear elements in fission yeast meiosis. Curr. Genet. 2012, 58, 119-127. [CrossRef]

30. Lorenz, A.; Wells, J.L.; Pryce, D.W.; Novatchkova, M.; Eisenhaber, F.; McFarlane, R.J.; Loidl, J.S. pombe meiotic linear elements contain proteins related to synaptonemal complex components. J. Cell Sci. 2004, 117, 3343-3351. [CrossRef]

31. Olson, L.W.; Eden, U.; Egel-Mitani, M.; Egel, R. Asynaptic meiosis in fission yeast? Hereditas 1978, 89, 189-199. [CrossRef]

32. Molnar, M.; Bahler, J.; Sipiczki, M.; Kohli, J. The rec8 gene of Schizosaccharomyces pombe is involved in linear element formation, chromosome pairing and sister-chromatid cohesion during meiosis. Genetics 1995, 141, 61-73. [CrossRef] [PubMed]

33. Schalbetter, S.A.; Fudenberg, G.; Baxter, J.; Pollard, K.S.; Neale, M.J. Principles of meiotic chromosome assembly revealed in S cerevisiae. Nat. Commun. 2019, 10, 4795. [CrossRef] [PubMed]

34. Muller, H.; Scolari, V.F.; Agier, N.; Piazza, A.; Thierry, A.; Mercy, G.; Descorps-Declere, S.; Lazar-Stefanita, L.; Espeli, O.; Llorente, B.; et al. Characterizing meiotic chromosomes' structure and pairing using a designer sequence optimized for Hi-C. Mol. Syst. Biol. 2018, 14, e8293. [CrossRef]

35. Sakuno, T.; Tashiro, S.; Tanizawa, H.; Iwasak, O.; Ding, D.; Haraguchi, T.; Noma, K.; Hiraoka, Y. Rec8 cohesin-mediated loop-axis chromatin architecture is required for meiotic recombination. BioRxiv 2021. [CrossRef]

36. Chatzidaki, E.E.; Powell, S.; Dequeker, B.J.H.; Gassler, J.; Silva, M.C.C.; Tachibana, K. Ovulation suppression protects against chromosomal abnormalities in mouse eggs at advanced maternal age. Curr. Biol. 2021, 31, 4038-4051.e4037. [CrossRef] [PubMed]

37. Nasmyth, K.; Haering, C.H. The structure and function of SMC and kleisin complexes. Annu. Rev. Biochem. 2005, 74, 595-648. [CrossRef] [PubMed] 
38. Haering, C.H.; Nasmyth, K. Building and breaking bridges between sister chromatids. Bioessays 2003, 25, 1178-1191. [CrossRef] [PubMed]

39. Onn, I.; Heidinger-Pauli, J.M.; Guacci, V.; Unal, E.; Koshland, D.E. Sister chromatid cohesion: A simple concept with a complex reality. Annu. Rev. Cell Dev. Biol. 2008, 24, 105-129. [CrossRef]

40. Mehta, G.D.; Kumar, R.; Srivastava, S.; Ghosh, S.K. Cohesin: Functions beyond sister chromatid cohesion. FEBS Lett. 2013, 587, 2299-2312. [CrossRef] [PubMed]

41. Nasmyth, K. Disseminating the genome: Joining, resolving, and separating sister chromatids during mitosis and meiosis. Annu. Rev. Genet. 2001, 35, 673-745. [CrossRef] [PubMed]

42. Ishiguro, K.I. The cohesin complex in mammalian meiosis. Genes Cells 2019, 24, 6-30. [CrossRef] [PubMed]

43. Ding, D.Q.; Okamasa, K.; Katou, Y.; Oya, E.; Nakayama, J.I.; Chikashige, Y.; Shirahige, K.; Haraguchi, T.; Hiraoka, Y. Chromosomeassociated RNA-protein complexes promote pairing of homologous chromosomes during meiosis in Schizosaccharomyces pombe. Nat. Commun. 2019, 10, 5598. [CrossRef] [PubMed]

44. Yamamoto, A.; Hiraoka, Y. How do meiotic chromosomes meet their homologous partners?: Lessons from fission yeast. Bioessays 2001, 23, 526-533. [CrossRef] [PubMed]

45. Hiraoka, Y. Phase separation drives pairing of homologous chromosomes. Curr. Genet. 2020, 66, 881-887. [CrossRef] [PubMed]

46. Chikashige, Y.; Ding, D.Q.; Funabiki, H.; Haraguchi, T.; Mashiko, S.; Yanagida, M.; Hiraoka, Y. Telomere-led premeiotic chromosome movement in fission yeast. Science 1994, 264, 270-273. [CrossRef]

47. Ding, D.Q.; Chikashige, Y.; Haraguchi, T.; Hiraoka, Y. Oscillatory nuclear movement in fission yeast meiotic prophase is driven by astral microtubules, as revealed by continuous observation of chromosomes and microtubules in living cells. J. Cell Sci. 1998, 111 Pt 6, 701-712. [CrossRef]

48. Takao, K.; Takamiya, K.; Ding, D.; Haraguchi, T.; Hiraoka, Y.; Nishimori, H.; Awazu, A. Torsional Turning Motion of Chromosomes as an Accelerating Force to Align Homologous Chromosomes during Meiosis. J. Phys. Soc. Jpn. 2019, 88, 023801. [CrossRef]

49. Chacón, M.R.; Delivani, P.; Tolić, I.M. Meiotic Nuclear Oscillations Are Necessary to Avoid Excessive Chromosome Associations. Cell Rep. 2016, 17, 1632-1645. [CrossRef]

50. Hiraoka, Y.; Dernburg, A.F. The SUN rises on meiotic chromosome dynamics. Dev. Cell 2009, 17, 598-605. [CrossRef]

51. Koszul, R.; Kleckner, N. Dynamic chromosome movements during meiosis: A way to eliminate unwanted connections? Trends Cell Biol. 2009, 19, 716-724. [CrossRef] [PubMed]

52. Ding, D.Q.; Haraguchi, T.; Hiraoka, Y. Chromosomally-retained RNA mediates homologous pairing. Nucleus 2012, 3, 516-519. [CrossRef] [PubMed]

53. Ding, D.Q.; Yamamoto, A.; Haraguchi, T.; Hiraoka, Y. Dynamics of homologous chromosome pairing during meiotic prophase in fission yeast. Dev. Cell 2004, 6, 329-341. [CrossRef]

54. Ding, D.Q.; Sakurai, N.; Katou, Y.; Itoh, T.; Shirahige, K.; Haraguchi, T.; Hiraoka, Y. Meiotic cohesins modulate chromosome compaction during meiotic prophase in fission yeast. J. Cell Biol. 2006, 174, 499-508. [CrossRef] [PubMed]

55. Ding, D.Q.; Matsuda, A.; Okamasa, K.; Nagahama, Y.; Haraguchi, T.; Hiraoka, Y. Meiotic cohesin-based chromosome structure is essential for homologous chromosome pairing in Schizosaccharomyces pombe. Chromosoma 2016, 125, 205-214. [CrossRef] [PubMed]

56. Covo, S.; Westmoreland, J.W.; Gordenin, D.A.; Resnick, M.A. Cohesin Is limiting for the suppression of DNA damage-induced recombination between homologous chromosomes. PLoS Genet. 2010, 6, e1001006. [CrossRef]

57. Schwacha, A.; Kleckner, N. Interhomolog bias during meiotic recombination: Meiotic functions promote a highly differentiated interhomolog-only pathway. Cell 1997, 90, 1123-1135. [CrossRef]

58. Kim, K.P.; Mirkin, E.V. So similar yet so different: The two ends of a double strand break. Mutat. Res. 2018, 809, 70-80. [CrossRef]

59. Kim, K.P.; Weiner, B.M.; Zhang, L.; Jordan, A.; Dekker, J.; Kleckner, N. Sister cohesion and structural axis components mediate homolog bias of meiotic recombination. Cell 2010, 143, 924-937. [CrossRef]

60. Lao, J.P.; Cloud, V.; Huang, C.C.; Grubb, J.; Thacker, D.; Lee, C.Y.; Dresser, M.E.; Hunter, N.; Bishop, D.K. Meiotic crossover control by concerted action of Rad51-Dmc1 in homolog template bias and robust homeostatic regulation. PLoS Genet. 2013, 9 , e1003978. [CrossRef]

61. Cromie, G.A.; Hyppa, R.W.; Taylor, A.F.; Zakharyevich, K.; Hunter, N.; Smith, G.R. Single Holliday junctions are intermediates of meiotic recombination. Cell 2006, 127, 1167-1178. [CrossRef]

62. Sakuno, T.; Tanaka, K.; Hauf, S.; Watanabe, Y. Repositioning of Aurora B promoted by chiasmata ensures sister chromatid mono-orientation in meiosis I. Dev. Cell 2011, 21, 534-545. [CrossRef]

63. Hirose, Y.; Suzuki, R.; Ohba, T.; Hinohara, Y.; Matsuhara, H.; Yoshida, M.; Itabashi, Y.; Murakami, H.; Yamamoto, A. Chiasmata promote monopolar attachment of sister chromatids and their co-segregation toward the proper pole during meiosis I. PLoS Genet. 2011, 7, e1001329. [CrossRef] [PubMed]

64. Yamamoto, A.; Hiraoka, Y. Monopolar spindle attachment of sister chromatids is ensured by two distinct mechanisms at the first meiotic division in fission yeast. EMBO J. 2003, 22, 2284-2296. [CrossRef] [PubMed]

65. Yokobayashi, S.; Yamamoto, M.; Watanabe, Y. Cohesins determine the attachment manner of kinetochores to spindle microtubules at meiosis I in fission yeast. Mol. Cell Biol. 2003, 23, 3965-3973. [CrossRef]

66. Heidmann, D.; Horn, S.; Heidmann, S.; Schleiffer, A.; Nasmyth, K.; Lehner, C.F. The Drosophila meiotic kleisin C(2)M functions before the meiotic divisions. Chromosoma 2004, 113, 177-187. [CrossRef] 
67. Rabitsch, K.P.; Toth, A.; Galova, M.; Schleiffer, A.; Schaffner, G.; Aigner, E.; Rupp, C.; Penkner, A.M.; Moreno-Borchart, A.C.; Primig, M.; et al. A screen for genes required for meiosis and spore formation based on whole-genome expression. Curr. Biol. 2001, 11, 1001-1009. [CrossRef]

68. Rabitsch, K.P.; Petronczki, M.; Javerzat, J.P.; Genier, S.; Chwalla, B.; Schleiffer, A.; Tanaka, T.U.; Nasmyth, K. Kinetochore recruitment of two nucleolar proteins is required for homolog segregation in meiosis I. Dev. Cell 2003, 4, 535-548. [CrossRef]

69. Tóth, A.; Rabitsch, K.P.; Gálová, M.; Schleiffer, A.; Buonomo, S.B.; Nasmyth, K. Functional genomics identifies monopolin: A kinetochore protein required for segregation of homologs during meiosis i. Cell 2000, 103, 1155-1168. [CrossRef]

70. Sakuno, T.; Tada, K.; Watanabe, Y. Kinetochore geometry defined by cohesion within the centromere. Nature 2009, 458, 852-858. [CrossRef]

71. Ogushi, S.; Rattani, A.; Godwin, J.; Metson, J.; Schermelleh, L.; Nasmyth, K. Loss of sister kinetochore co-orientation and peri-centromeric cohesin protection after meiosis I depends on cleavage of centromeric REC8. Dev. Cell 2021, 56, 3100-3114.e3104. [CrossRef] [PubMed]

72. Kim, J.; Ishiguro, K.; Nambu, A.; Akiyoshi, B.; Yokobayashi, S.; Kagami, A.; Ishiguro, T.; Pendas, A.M.; Takeda, N.; Sakakibara, Y.; et al. Meikin is a conserved regulator of meiosis-I-specific kinetochore function. Nature 2015, 517, 466-471. [CrossRef] [PubMed]

73. Miyazaki, S.; Kim, J.; Yamagishi, Y.; Ishiguro, T.; Okada, Y.; Tanno, Y.; Sakuno, T.; Watanabe, Y. Meikin-associated polo-like kinase specifies Bub1 distribution in meiosis I. Genes Cells 2017, 22, 552-567. [CrossRef] [PubMed]

74. Galander, S.; Barton, R.E.; Borek, W.E.; Spanos, C.; Kelly, D.A.; Robertson, D.; Rappsilber, J.; Marston, A.L. Reductional Meiosis I Chromosome Segregation Is Established by Coordination of Key Meiotic Kinases. Dev. Cell 2019, 49, 526-541.e525. [CrossRef] [PubMed]

75. Katis, V.L.; Matos, J.; Mori, S.; Shirahige, K.; Zachariae, W.; Nasmyth, K. Spo13 facilitates monopolin recruitment to kinetochores and regulates maintenance of centromeric cohesion during yeast meiosis. Curr. Biol. 2004, 14, 2183-2196. [CrossRef] [PubMed]

76. Lee, B.H.; Kiburz, B.M.; Amon, A. Spo13 maintains centromeric cohesion and kinetochore coorientation during meiosis I. Curr. Biol. 2004, 14, 2168-2182. [CrossRef]

77. Mehta, G.; Anbalagan, G.K.; Bharati, A.P.; Gadre, P.; Ghosh, S.K. An interplay between Shugoshin and Spo13 for centromeric cohesin protection and sister kinetochore mono-orientation during meiosis I in Saccharomyces cerevisiae. Curr. Genet. 2018, 64, 1141-1152. [CrossRef]

78. Petronczki, M.; Matos, J.; Mori, S.; Gregan, J.; Bogdanova, A.; Schwickart, M.; Mechtler, K.; Shirahige, K.; Zachariae, W.; Nasmyth K. Monopolar attachment of sister kinetochores at meiosis I requires casein kinase 1. Cell 2006, 126, 1049-1064. [CrossRef]

79. Moore, D.P.; Orr-Weaver, T.L. Chromosome segregation during meiosis: Building an unambivalent bivalent. Curr. Top. Dev. Biol. 1998, 37, 263-299.

80. Watanabe, Y.; Nurse, P. Cohesin Rec8 is required for reductional chromosome segregation at meiosis. Nature 1999, 400, 461-464. [CrossRef]

81. Chen, S.Y.; Tsubouchi, T.; Rockmill, B.; Sandler, J.S.; Richards, D.R.; Vader, G.; Hochwagen, A.; Roeder, G.S.; Fung, J.C. Global analysis of the meiotic crossover landscape. Dev. Cell 2008, 15, 401-415. [CrossRef] [PubMed]

82. Mancera, E.; Bourgon, R.; Brozzi, A.; Huber, W.; Steinmetz, L.M. High-resolution mapping of meiotic crossovers and noncrossovers in yeast. Nature 2008, 454, 479-485. [CrossRef] [PubMed]

83. Beadle, G.W. A Possible Influence of the Spindle Fibre on Crossing-Over in Drosophila. Proc. Natl. Acad. Sci. USA 1932, 18, 160-165. [CrossRef] [PubMed]

84. Rockmill, B.; Voelkel-Meiman, K.; Roeder, G.S. Centromere-proximal crossovers are associated with precocious separation of sister chromatids during meiosis in Saccharomyces cerevisiae. Genetics 2006, 174, 1745-1754. [CrossRef] [PubMed]

85. Hassold, T.; Hunt, P. To err (meiotically) is human: The genesis of human aneuploidy. Nat. Rev. Genet. 2001, 2, 280-291. [CrossRef] [PubMed]

86. Kitajima, T.S.; Kawashima, S.A.; Watanabe, Y. The conserved kinetochore protein shugoshin protects centromeric cohesion during meiosis. Nature 2004, 427, 510-517. [CrossRef] [PubMed]

87. Indjeian, V.B.; Stern, B.M.; Murray, A.W. The centromeric protein Sgo1 is required to sense lack of tension on mitotic chromosomes. Science 2005, 307, 130-133. [CrossRef]

88. Katis, V.L.; Galova, M.; Rabitsch, K.P.; Gregan, J.; Nasmyth, K. Maintenance of cohesin at centromeres after meiosis I in budding yeast requires a kinetochore-associated protein related to MEI-S332. Curr. Biol. 2004, 14, 560-572. [CrossRef]

89. Kitajima, T.S.; Sakuno, T.; Ishiguro, K.; Iemura, S.; Natsume, T.; Kawashima, S.A.; Watanabe, Y. Shugoshin collaborates with protein phosphatase 2A to protect cohesin. Nature 2006, 441, 46-52. [CrossRef]

90. Riedel, C.G.; Katis, V.L.; Katou, Y.; Mori, S.; Itoh, T.; Helmhart, W.; Gálová, M.; Petronczki, M.; Gregan, J.; Cetin, B.; et al. Protein phosphatase 2A protects centromeric sister chromatid cohesion during meiosis I. Nature 2006, 441, 53-61. [CrossRef]

91. Ishiguro, T.; Tanaka, K.; Sakuno, T.; Watanabe, Y. Shugoshin-PP2A counteracts casein-kinase-1-dependent cleavage of Rec8 by separase. Nat. Cell Biol. 2010, 12, 500-506. [CrossRef] [PubMed]

92. Lee, J.; Kitajima, T.S.; Tanno, Y.; Yoshida, K.; Morita, T.; Miyano, T.; Miyake, M.; Watanabe, Y. Unified mode of centromeric protection by shugoshin in mammalian oocytes and somatic cells. Nat. Cell Biol. 2008, 10, 42-52. [CrossRef] [PubMed]

93. Yin, S.; Ai, J.S.; Shi, L.H.; Wei, L.; Yuan, J.; Ouyang, Y.C.; Hou, Y.; Chen, D.Y.; Schatten, H.; Sun, Q.Y. Shugoshin1 may play important roles in separation of homologous chromosomes and sister chromatids during mouse oocyte meiosis. PLOS ONE 2008, 3, e3516. [CrossRef] [PubMed] 
94. Sun, X.; Huang, L.; Markowitz, T.E.; Blitzblau, H.G.; Chen, D.; Klein, F.; Hochwagen, A. Transcription dynamically patterns the meiotic chromosome-axis interface. Elife 2015, 4, e07424. [CrossRef] [PubMed]

95. Panizza, S.; Mendoza, M.A.; Berlinger, M.; Huang, L.; Nicolas, A.; Shirahige, K.; Klein, F. Spo11-accessory proteins link double-strand break sites to the chromosome axis in early meiotic recombination. Cell 2011, 146, 372-383. [CrossRef] [PubMed]

96. Sakuno, T.; Watanabe, Y. Phosphorylation of cohesin Rec11/SA3 by casein kinase 1 promotes homologous recombination by assembling the meiotic chromosome axis. Dev. Cell 2015, 32, 220-230. [CrossRef]

97. Phadnis, N.; Cipak, L.; Polakova, S.; Hyppa, R.W.; Cipakova, I.; Anrather, D.; Karvaiova, L.; Mechtler, K.; Smith, G.R.; Gregan, J Casein Kinase 1 and Phosphorylation of Cohesin Subunit Rec11 (SA3) Promote Meiotic Recombination through Linear Element Formation. PLoS Genet. 2015, 11, e1005225. [CrossRef]

98. Ponticelli, A.S.; Smith, G.R. Meiotic recombination-deficient mutants of Schizosaccharomyces pombe. Genetics 1989, 123, 45-54. [CrossRef]

99. Miyoshi, T.; Ito, M.; Kugou, K.; Yamada, S.; Furuichi, M.; Oda, A.; Yamada, T.; Hirota, K.; Masai, H.; Ohta, K. A central coupler for recombination initiation linking chromosome architecture to S phase checkpoint. Mol. Cell 2012, 47, 722-733. [CrossRef]

100. Biswas, U.; Hempel, K.; Llano, E.; Pendas, A.; Jessberger, R. Distinct Roles of Meiosis-Specific Cohesin Complexes in Mammalian Spermatogenesis. PLoS Genet. 2016, 12, e1006389. [CrossRef]

101. Ward, A.; Hopkins, J.; Mckay, M.; Murray, S.; Jordan, P.W. Genetic Interactions Between the Meiosis-Specific Cohesin Components, STAG3, REC8, and RAD21L. G3 Genes Genomes Genet. 2016, 6, 1713-1724. [CrossRef] [PubMed]

102. Fukuda, T.; Pratto, F.; Schimenti, J.C.; Turner, J.M.; Camerini-Otero, R.D.; Hoog, C. Phosphorylation of chromosome core components may serve as axis marks for the status of chromosomal events during mammalian meiosis. PLoS Genet. 2012, 8 , e1002485. [CrossRef] [PubMed]

103. Pasierbek, P.; Fodermayr, M.; Jantsch, V.; Jantsch, M.; Schweizer, D.; Loidl, J. The Caenorhabditis elegans SCC-3 homologue is required for meiotic synapsis and for proper chromosome disjunction in mitosis and meiosis. Exp. Cell Res. 2003, 289, 245-255. [CrossRef]

104. Fukuda, T.; Daniel, K.; Wojtasz, L.; Toth, A.; Höög, C. A novel mammalian HORMA domain-containing protein, HORMAD1, preferentially associates with unsynapsed meiotic chromosomes. Exp. Cell Res. 2010, 316, 158-171. [CrossRef] [PubMed]

105. Pelttari, J.; Hoja, M.R.; Yuan, L.; Liu, J.G.; Brundell, E.; Moens, P.; Santucci-Darmanin, S.; Jessberger, R.; Barbero, J.L.; Heyting, C.; et al. A meiotic chromosomal core consisting of cohesin complex proteins recruits DNA recombination proteins and promotes synapsis in the absence of an axial element in mammalian meiotic cells. Mol. Cell Biol. 2001, 21, 5667-5677. [CrossRef]

106. Zickler, D.; Kleckner, N. Meiotic chromosomes: Integrating structure and function. Annu. Rev. Genet. 1999, 33, 603-754. [CrossRef]

107. Patel, L.; Kang, R.; Rosenberg, S.C.; Qiu, Y.; Raviram, R.; Chee, S.; Hu, R.; Ren, B.; Cole, F.; Corbett, K.D. Dynamic reorganization of the genome shapes the recombination landscape in meiotic prophase. Nat. Struct. Mol. Biol. 2019, 26, 164-174. [CrossRef]

108. Silva, M.C.C.; Powell, S.; Ladstätter, S.; Gassler, J.; Stocsits, R.; Tedeschi, A.; Peters, J.M.; Tachibana, K. Wapl releases Scc1-cohesin and regulates chromosome structure and segregation in mouse oocytes. J. Cell Biol. 2020, 219, e201906100. [CrossRef]

109. Wang, Y.; Wang, H.; Zhang, Y.; Du, Z.; Si, W.; Fan, S.; Qin, D.; Wang, M.; Duan, Y.; Li, L.; et al. Reprogramming of Meiotic Chromatin Architecture during Spermatogenesis. Mol. Cell 2019, 73, 547-561.e546. [CrossRef]

110. Luo, Z.; Wang, X.; Jiang, H.; Wang, R.; Chen, J.; Chen, Y.; Xu, Q.; Cao, J.; Gong, X.; Wu, J.; et al. Reorganized 3D Genome Structures Support Transcriptional Regulation in Mouse Spermatogenesis. iScience 2020, 23, 101034. [CrossRef]

111. Alavattam, K.G.; Maezawa, S.; Sakashita, A.; Khoury, H.; Barski, A.; Kaplan, N.; Namekawa, S.H. Attenuated chromatin compartmentalization in meiosis and its maturation in sperm development. Nat. Struct. Mol. Biol. 2019, 26, 175-184. [CrossRef]

112. Zuo, W.; Chen, G.; Gao, Z.; Li, S.; Chen, Y.; Huang, C.; Chen, J.; Chen, Z.; Lei, M.; Bian, Q. Stage-resolved Hi-C analyses reveal meiotic chromosome organizational features influencing homolog alignment. Nat. Commun. 2021, 12, 5827. [CrossRef] [PubMed]

113. Du, Z.; Zheng, H.; Kawamura, Y.K.; Zhang, K.; Gassler, J.; Powell, S.; Xu, Q.; Lin, Z.; Xu, K.; Zhou, Q.; et al. Polycomb Group Proteins Regulate Chromatin Architecture in Mouse Oocytes and Early Embryos. Mol. Cell 2020, 77, 825-839. [CrossRef] [PubMed]

114. Vara, C.; Paytuví-Gallart, A.; Cuartero, Y.; Le Dily, F.; Garcia, F.; Salvà-Castro, J.; Gómez-H, L.; Julià, E.; Moutinho, C.; Aiese Cigliano, R.; et al. Three-Dimensional Genomic Structure and Cohesin Occupancy Correlate with Transcriptional Activity during Spermatogenesis. Cell Rep. 2019, 28, 352-367.e359. [CrossRef] [PubMed]

115. Luo, Z.; Hu, T.; Jiang, H.; Wang, R.; Xu, Q.; Zhang, S.; Cao, J.; Song, X. Rearrangement of macronucleus chromosomes correspond to TAD-like structures of micronucleus chromosomes in. Genome Res. 2020, 30, 406-414. [CrossRef]

116. Costantino, L.; Hsieh, T.S.; Lamothe, R.; Darzacq, X.; Koshland, D. Cohesin residency determines chromatin loop patterns. Elife 2020, 9, e59889. [CrossRef]

117. Del Mazo, J.; Gil-Alberdi, L. Multistranded organization of the lateral elements of the synaptonemal complex in the rat and mouse. Cytogenet. Genome Res. 1986, 41, 219-224. [CrossRef]

118. Kierszenbaum, A.L.; Tres, L.L. Transcription sites in spread meiotic prophase chromosomes from mouse spermatocytes. J. Cell Biol. 1974, 63, 923-935. [CrossRef]

119. Kim, Y.; Shi, Z.; Zhang, H.; Finkelstein, I.J.; Yu, H. Human cohesin compacts DNA by loop extrusion. Science 2019, 366, 1345-1349. [CrossRef]

120. Davidson, I.F.; Peters, J.M. Genome folding through loop extrusion by SMC complexes. Nat. Rev. Mol. Cell Biol. 2021, 22, 445-464. [CrossRef] 
121. Mizuguchi, T.; Fudenberg, G.; Mehta, S.; Belton, J.M.; Taneja, N.; Folco, H.D.; FitzGerald, P.; Dekker, J.; Mirny, L.; Barrowman, J.; et al. Cohesin-dependent globules and heterochromatin shape 3D genome architecture in S. pombe. Nature 2014, 516, 432-435. [CrossRef] [PubMed]

122. Fudenberg, G.; Imakaev, M.; Lu, C.; Goloborodko, A.; Abdennur, N.; Mirny, L.A. Formation of Chromosomal Domains by Loop Extrusion. Cell Rep. 2016, 15, 2038-2049. [CrossRef] [PubMed]

123. Rao, S.S.P.; Huang, S.C.; Glenn St Hilaire, B.; Engreitz, J.M.; Perez, E.M.; Kieffer-Kwon, K.R.; Sanborn, A.L.; Johnstone, S.E.; Bascom, G.D.; Bochkov, I.D.; et al. Cohesin Loss Eliminates All Loop Domains. Cell 2017, 171, 305-320.e324. [CrossRef]

124. Hartman, T.; Stead, K.; Koshland, D.; Guacci, V. Pds5p is an essential chromosomal protein required for both sister chromatid cohesion and condensation in Saccharomyces cerevisiae. J. Cell Biol. 2000, 151, 613-626. [CrossRef] [PubMed]

125. Panizza, S.; Tanaka, T.; Hochwagen, A.; Eisenhaber, F.; Nasmyth, K. Pds5 cooperates with cohesin in maintaining sister chromatid cohesion. Curr. Biol. 2000, 10, 1557-1564. [CrossRef]

126. Stead, K.; Aguilar, C.; Hartman, T.; Drexel, M.; Meluh, P.; Guacci, V. Pds5p regulates the maintenance of sister chromatid cohesion and is sumoylated to promote the dissolution of cohesion. J. Cell Biol. 2003, 163, 729-741. [CrossRef] [PubMed]

127. Tanaka, K.; Hao, Z.; Kai, M.; Okayama, H. Establishment and maintenance of sister chromatid cohesion in fission yeast by a unique mechanism. EMBO J. 2001, 20, 5779-5790. [CrossRef]

128. Gandhi, R.; Gillespie, P.J.; Hirano, T. Human Wapl is a cohesin-binding protein that promotes sister-chromatid resolution in mitotic prophase. Curr. Biol. 2006, 16, 2406-2417. [CrossRef]

129. Kueng, S.; Hegemann, B.; Peters, B.H.; Lipp, J.J.; Schleiffer, A.; Mechtler, K.; Peters, J.M. Wapl controls the dynamic association of cohesin with chromatin. Cell 2006, 127, 955-967. [CrossRef]

130. Nishiyama, T.; Ladurner, R.; Schmitz, J.; Kreidl, E.; Schleiffer, A.; Bhaskara, V.; Bando, M.; Shirahige, K.; Hyman, A.A.; Mechtler K.; et al. Sororin mediates sister chromatid cohesion by antagonizing Wapl. Cell 2010, 143, 737-749. [CrossRef]

131. Challa, K.; Lee, M.S.; Shinohara, M.; Kim, K.P.; Shinohara, A. Rad61/Wpl1 (Wapl), a cohesin regulator, controls chromosome compaction during meiosis. Nucleic Acids Res. 2016, 44, 3190-3203. [CrossRef] [PubMed]

132. Challa, K.; Shinohara, M.; Shinohara, A. Meiotic prophase-like pathway for cleavage-independent removal of cohesin for chromosome morphogenesis. Curr. Genet. 2019, 65, 817-827. [CrossRef] [PubMed]

133. Haarhuis, J.H.I.; van der Weide, R.H.; Blomen, V.A.; Yáñez-Cuna, J.O.; Amendola, M.; van Ruiten, M.S.; Krijger, P.H.L.; Teunissen, H.; Medema, R.H.; van Steensel, B.; et al. The Cohesin Release Factor WAPL Restricts Chromatin Loop Extension. Cell 2017, 169, 693-707.e614. [CrossRef] [PubMed]

134. Hong, S.; Joo, J.H.; Yun, H.; Kleckner, N.; Kim, K.P. Recruitment of Rec8, Pds5 and Rad61/Wapl to meiotic homolog pairing, recombination, axis formation and S-phase. Nucleic Acids Res. 2019, 47, 11691-11708. [CrossRef]

135. Tedeschi, A.; Wutz, G.; Huet, S.; Jaritz, M.; Wuensche, A.; Schirghuber, E.; Davidson, I.F.; Tang, W.; Cisneros, D.A.; Bhaskara, V.; et al. Wapl is an essential regulator of chromatin structure and chromosome segregation. Nature 2013, 501, 564-568. [CrossRef]

136. Viera, A.; Berenguer, I.; Ruiz-Torres, M.; Gómez, R.; Guajardo, A.; Barbero, J.L.; Losada, A.; Suja, J.A. PDS5 proteins regulate the length of axial elements and telomere integrity during male mouse meiosis. EMBO Rep. 2020, 21, e49273. [CrossRef]

137. Jin, H.; Guacci, V.; Yu, H.G. Pds5 is required for homologue pairing and inhibits synapsis of sister chromatids during yeast meiosis. J. Cell Biol. 2009, 186, 713-725. [CrossRef]

138. Crawley, O.; Barroso, C.; Testori, S.; Ferrandiz, N.; Silva, N.; Castellano-Pozo, M.; Jaso-Tamame, A.L.; Martinez-Perez, E. Cohesininteracting protein WAPL-1 regulates meiotic chromosome structure and cohesion by antagonizing specific cohesin complexes. Elife 2016, 5, e10851. [CrossRef]

139. Wutz, G.; Várnai, C.; Nagasaka, K.; Cisneros, D.A.; Stocsits, R.R.; Tang, W.; Schoenfelder, S.; Jessberger, G.; Muhar, M.; Hossain, M.J.; et al. Topologically associating domains and chromatin loops depend on cohesin and are regulated by CTCF, WAPL, and PDS5 proteins. EMBO J. 2017, 36, 3573-3599. [CrossRef]

140. Li, Y.; Haarhuis, J.H.I.; Sedeño Cacciatore, Á.; Oldenkamp, R.; van Ruiten, M.S.; Willems, L.; Teunissen, H.; Muir, K.W.; de Wit, E.; Rowland, B.D.; et al. The structural basis for cohesin-CTCF-anchored loops. Nature 2020, 578, 472-476. [CrossRef]

141. Nora, E.P.; Goloborodko, A.; Valton, A.L.; Gibcus, J.H.; Uebersohn, A.; Abdennur, N.; Dekker, J.; Mirny, L.A.; Bruneau, B.G. Targeted Degradation of CTCF Decouples Local Insulation of Chromosome Domains from Genomic Compartmentalization. Cell 2017, 169, 930-944.e922. [CrossRef] [PubMed]

142. Rao, S.S.; Huntley, M.H.; Durand, N.C.; Stamenova, E.K.; Bochkov, I.D.; Robinson, J.T.; Sanborn, A.L.; Machol, I.; Omer, A.D.; Lander, E.S.; et al. A 3D map of the human genome at kilobase resolution reveals principles of chromatin looping. Cell 2014, 159, 1665-1680. [CrossRef] [PubMed]

143. Davidson, I.F.; Bauer, B.; Goetz, D.; Tang, W.; Wutz, G.; Peters, J.M. DNA loop extrusion by human cohesin. Science 2019, 366, 1338-1345. [CrossRef] [PubMed]

144. Ganji, M.; Shaltiel, I.A.; Bisht, S.; Kim, E.; Kalichava, A.; Haering, C.H.; Dekker, C. Real-time imaging of DNA loop extrusion by condensin. Science 2018, 360, 102-105. [CrossRef] [PubMed]

145. Kim, E.; Kerssemakers, J.; Shaltiel, I.A.; Haering, C.H.; Dekker, C. DNA-loop extruding condensin complexes can traverse one another. Nature 2020, 579, 438-442. [CrossRef]

146. Kschonsak, M.; Merkel, F.; Bisht, S.; Metz, J.; Rybin, V.; Hassler, M.; Haering, C.H. Structural Basis for a Safety-Belt Mechanism That Anchors Condensin to Chromosomes. Cell 2017, 171, 588-600.e524. [CrossRef] 
147. Terakawa, T.; Bisht, S.; Eeftens, J.M.; Dekker, C.; Haering, C.H.; Greene, E.C. The condensin complex is a mechanochemical motor that translocates along DNA. Science 2017, 358, 672-676. [CrossRef]

148. Hore, T.A.; Deakin, J.E.; Marshall Graves, J.A. The evolution of epigenetic regulators CTCF and BORIS/CTCFL in amniotes. PLoS Genet. 2008, 4, e1000169. [CrossRef]

149. Barbero, J.L. Genetic basis of cohesinopathies. Appl. Clin. Genet. 2013, 6, 15-23. [CrossRef]

150. Liu, J.; Zhang, Z.; Bando, M.; Itoh, T.; Deardorff, M.A.; Clark, D.; Kaur, M.; Tandy, S.; Kondoh, T.; Rappaport, E.; et al. Transcriptional dysregulation in NIPBL and cohesin mutant human cells. PLoS Biol. 2009, 7, e1000119. [CrossRef] 